\title{
DOUBLE TAXATION CONVENTIONS IN CENTRAL AND EASTERN EUROPEAN COUNTRIES
}

\author{
Florin Dumiter $\mathbf{P h D}^{1,2}$ \\ 1"Vasile Goldis" Western University of Arad \\ ${ }^{2}$ West University of Timisoara, Faculty of Law, PhD Candidate \\ E-mail: fdumiter@yahoo.com
}

Stefania Jimon Master Student

"Vasile Goldiș" Western University of Arad E-mail: jimonstefania@yahoo.com

(Received September 2016; Accepted November 2016)

\begin{abstract}
In this article we provide a qualitative overview regarding the panacea of double taxation conventions in Central and Eastern European Countries. Double taxation paradigm highlights some serious problems arising from multiple taxation of the same income or capital. In the European Union these problems suggest that there is a strong need of a "best practice" construction of an optimal fiscal space in order to eliminate or reduce this problem. Central and Eastern European Countries have some special features: on one hand these countries have been influenced by the communist and postcommunism era, and on the other hand there are specific particularities for each country which must be economically and judicially understood and explained. This article highlights the structure, construction and appliance of the double taxation conventions in the Central and Eastern European Countries. The conclusions of this article enact the solutions of the potential problems of double taxation, especially in these former communist countries, with respect to the strengthening of the new fiscal space in the European Union.

Keywords: Central and Eastern European Countries, Double Taxation Conventions, Anti Abuse Provisions, Judicial and Economical Double Taxation, Cooperation Protocol.

JEL classification: H24, H30, K34, K40.

\section{Introduction}

Different interpretations of fiscal legislation at international level can lead to a series of conflicts [1], ,the most common being international double taxation, tax avoidance, the problem of tax heavens, discrimination between domestic and foreign taxpayers, harmful tax competition."'[2]

In juridical and economic literature the problem of international double taxation and conventions, by trying its avoidance is often treated, one side because of the negative effects which this situation has got under world economy, and on the other side because of juridical implications manifested at sovereignty and domestic legislation level. Also, discussions regarding setting forth some „abusive cases” after an improper interpretation of international fiscal legislation are not excluded.
\end{abstract}




\section{JOURNAL OF LEGAL STUDIES}

"Vasile Goldiş" Western University of Arad

Dumiter F., Jimon S. (2016)

Double Taxation Conventions in Central and Eastern European Countries

International double taxation is defined as the situation in which two or more fiscal sovereignty or competences are exercising fiscal authority on the same taxable object.[3] This emerges in the case of a state which claims jurisdiction on the income or capital based on their origin, and the other state based on taxpayer residency.

So, international double taxation became a concern for the Organisation for Economic Co-operation and Development, United Nations Organisation, European Union and world states because it can lead to repression of international trade relationships. [4]

To avoid the appearance of international double taxation bilateral treaties were signed, for the contracting states to establish and define the circumstances in which taxation will be carried out in the source state and resident one.[5] By structure and bilateral nature of these treaties, both states make compromises regarding fiscal sovereignty and taxation right, according to the existing economic and political relationship.[6]

Agreements signed for international double taxation avoidance have as main objectives to ,reduce or eliminate the burden of double taxation on the same income, establish cooperation between the taxing authorities of the contracting states, promote trade and investment between contracting states through clauses that permit the establishment of a tax burden that does not hamper the normal flow of capital, provide a fair division of tax revenues between contracting states and combat tax evasion and fiscal fraud".[7]

Signing such treaties and their implementation generates a series of changes in national plan, for every contracting state. Through the benefits conferred encouraging direct foreign investment is included, as well as reducing investors' uncertainty regarding a foreign tax system, combating tax evasion, avoiding double nontaxation, reducing harmful tax competition. But there are also some costs that involve signing such a treaty. So, the adaptation of different legislation requires hard work; some stipulations can be in a contradiction with national legislation, which can affect state sovereignty, and not at last, the possibility of losing some fiscal incomes may emerge, given that taxation is applied depending on taxpayer residency.[8]

International double taxation agreements are part of the international fiscal right and enter into force after being ratified by both states. At national level, these agreements have priority application over domestic legislation and these can be modified by a new agreement or a protocol.

Between Central and Eastern European Countries in this paper we will refer especially to the Czech Republic, Slovakia, Poland, Hungary and Romania. All these were influenced by the communism totalitarian system and after its crash, went through an extensive process of economic development. Since joining and 
integration into the European Union this process continued and led to a closer international cooperation.

The purpose of this paper is to highlight how excountries led by communism auspices have managed to adapt to the market liberalization process and integration into the European space. Also, the paper wants to present the way in which international double taxation avoidance was carried out as well as a comparative study regarding the agreements to avoid double taxation signed by these countries. Finally, are presented some conclusions arising from analysis of agreements to avoid international double taxation signed by these five state members of the European Union.

\section{The framework of international double taxation}

International double taxation is defined as being direct taxation of same taxable item and for the same time period, by fiscal authorities of different states.[9] This situation appears in the context of globalization and free movement of goods, services, persons and capital. Thereby, appears an interstate competition, each state wanting to be more attractive in terms of tax for their taxpayers and by this way cause the increasing of foreign investments at national level. [10]

Tax sovereignty of each state supposing that it has ,the liberty to establish tax system that is instituted, to define the taxes which compose this system, to specify taxing subjects, to size tax rates, to fix payments terms, to give tax facilities, to establish tax penalties, to establish appeal ways and the procedure to resolution of tax disputes, etc."'[11] In other words, each state establishes the way of taxing his own citizens and nonresident persons who obtain income or own properties on their territory [12] and in these conditions can emerge the situation of an overlapping regarding tax jurisdiction and international double taxation.

To eliminate this situation, lots of states signed bilateral agreements, most of them based on the Organisation for Economic Co-operation and Development model. This model represents "a noncompulsory format and negotiation platform between states"[13] through is establish each state competency about taxing realized income and owned properties by nonresidents. Importance and necessity to sign such agreements is sustained by encouraging and stimulating international trade relationships.[14]

At the end of $20^{\text {th }}$ century Central and Eastern European countries began a process of development and reorganization, both in political terms, but also economic and social. Enhancement of international economic relationships and passing at market economy has meant a series of reforms regarding tax system. This process was emphasized by accession and integration into the European Union due to the need to implement and harmonize domestic legislation with Community legislation. 


\section{JOURNAL OF LEGAL STUDIES}

"Vasile Goldiș" Western University of Arad

Dumiter F., Jimon S. (2016)

Double Taxation Conventions in Central and Eastern European Countries

Regarding international double taxation problem, Central and Eastern European countries signed many agreements with worldwide states to avoid this situation. Although these treaties are part of international rights and have a priority application against domestic legislation, ,are noticed still keeping the tax sovereignty of member states"[15], these being mutual agreements which specifies the limitation of imposing right.

To avoid international double taxation, the Czech Republic gives, according to signed treaties an exemption or a credit for foreign tax paid, and in the case in which a convention to avoid international double taxation is not applied, the foreign tax paid can be deducted as an expend. Poland, Slovakia and Romania establish to give a fiscal credit for the tax paid in a contracting country up to the limit of the tax value which should be paid in the resident country for same income. Some of the agreements signed by Slovakia provide international double taxation avoidance by total exemption method, which presume that taxed incomes in the partner country will be excluded from tax in Slovakia. Hungary, through signed treaties gives an exemption or a fiscal credit for taxed incomes in a contracting country, and in case that does not exist, an international agreement to avoid double taxation, domestic tax legislation presumes granting a credit for the foreign tax paid.[16]

\section{Comparative analysis of convention to avoid international double taxation in Central and Eastern European countries}

Central and Eastern European countries have a considerable number of conventions and protocols signed to avoid international double taxation, the most common being those for avoiding double taxation of incomes and capital.

After processing data published in databases of the United Nations Conference on Trade and Development, the European Union and ministries of finance of these states we noticed that Czech Republic totals 82 of such treaties, Poland 110, Slovakia 69, Hungary 84 and Romania 90.

Analyzing these aspects, we could observe that the oldest agreement is dated in 1937 and has as object avoidance double taxation of inheritances, being contracted by Hungary and Sweden. Next convention was signed in the year of 1950 for sea and air transport between Poland and Argentine, followed by treaties signed by Czech Republic and Slovakia with Switzerland in 1960 for air transport.

Regarding avoidance of incomes and capital double taxation, Czech Republic has the oldest treaty signed with France in 1973, this being modified in 2005 and is followed by the agrement signed with the Netherlands in 1974, which is in force even today. In the year of 1980 were also signed agreements with the following states: Belgium, which was modified in 2000, Japan, Sri Lanka and Sweden. Between 1980 and 1990, Czech Republic signed such treaties with Germany, Spain, Italy, Brazil, Greece, Nigeria, Canada, Tunisia and Great Britain, and after 
1990 have been signed other 37 new agreements with states from all over the world. Starting with the year 2000 were closed conventions to avoid international double taxation with Island, Philippines, Uzbekistan, Mexico, Slovakia, Norway, Serbia and Montenegro, South Korea, Austria, Georgia, Bosnia and Herzegovina, Armenia, Macedonia, Kuwait, Tajikistan, Armenia. Also during these years took place the modification of conventions with Belgium, Latvia, Turkey, France, Poland and Denmark.

The Czech Republic has 11 conventions to avoid income double taxation. The first agreement was signed in 1980 with Cyprus, but it was modified in 2009; it was followed by the one signed with South Korea in 1992, which was also modified in 2005. From the year of 2005 have been closed conventions with Azerbaijan, Jordan, Morocco, Ethiopia, New Zeeland and Syria, though the last ones have been signed with China, Bahrain, Barbados, Hong Kong and Saudi Arabia.

The Czech Republic has signed an agreement to avoid double taxation of companies which operate in the field of air transport with Switzerland since 1960 and one agreement with USA to avoid double taxation of contribution for social security, agreement closed in 2007.

Poland has five types of agreements to avoid international double taxation, most of them regarding avoidance of income and capital double taxation. Such an agreement was first closed in 1972 with Germany, being modified in 2003. Until 1980 have been signed agreements with Pakistan, USA, France, Malaysia and Spain, being in force until today the agreements closed with Pakistan, France and Spain. In the period 1980 - 1990 have been signed agreements with Japan, Sri Lanka, modified in 2015, Italy, Canada, which was modified in 2012, Greece, China and India. Between 1990 and 2000 have been closed over 30 such treaties with worldwide states; after 2000 new agreements with Algeria, Hungary, Belgium, Denmark, Chile, Kuwait, Tajikistan and Austria were signed. The most recent treaties were signed in 2009 to bring some modifications and updates in the collaboration relationship with Finland and Norway.

Regarding the avoidance of incomes double taxation, Poland has closed treaties with 39 states. The first agreement was closed in 1974 with Pakistan, being followed by the ones closed with Malaysia and Thailand. Between 1980 and 1990 have been signed conventions with Japan, Italy, China and India, applied until today. In period 1990 - 2000 have been closed other 22 new agreements, and after the year of 2000 treaties have been closed with Syria, Sweden, New Zeeland, Qatar, Saudi Arabia, Man Island, Jersey, Guernsey and the last in 2015 with Ethiopia.

Poland has closed five treaties to avoid double taxation of companies which operate in the field of sea and naval transport. First was closed in 1950 with Argentina, followed by the ones with Switzerland, Man Island, Jersey and 


\section{JOURNAL OF LEGAL STUDIES}

"Vasile Goldiș" Western University of Arad

Dumiter F., Jimon S. (2016)

Double Taxation Conventions in Central and Eastern European Countries

Guernsey. Also, since 2006 Poland sign with Macedonia a treaty for the avoidance of double taxation regarding contributions for social security. Not last, from 2000 until 2014 have been closed 15 protocols to ensure good cooperation at international level.

Slovakia has four types of conventions to avoid international double taxation, most interesting incomes and capital. The first agreement closed dates back in 1973 and was signed with France, followed in 1974 by the one closed with the Netherlands, and then with Japan, Austria, Portugal, which was modified in 2001, Sri Lanka, Norway and Sweden. Between 1980 and 1990 have been signed agreements with Cyprus, Germany, Spain, Italy, Denmark, Brazil, Greece, India, China and Norway, which are applied until today. In period 1990 - 2000 have been closed 22 treaties, 16 from these being with states from the European territory and after the year of 2000 other 13 treaties were signed, most recent being with Kuwait in 2012. From treaties closed to avoid international double taxation of incomes, first was closed with Turkey in 1997, followed in 2000 by the one with Indonesia and in 2001 with Korea and Portugal. From 2004 have been signed agreements with Egypt, Singapore, Mexico, Vietnam, Syria and Libya.

Slovakia closed in 1960 a convention with Switzerland to avoid double taxation of activities developed by entities which operate in the field of air transport and also, has closed protocols to ensure good cooperation with Poland, Switzerland and the Netherlands.

Hungary also has four types of agreements closed to avoid international double taxation, the most having as object incomes and capital. The first treaty closed in 1975 with Austria is applied until today, being followed by the agreements with Germany, Italy, Great Britain, Egypt and Finland, from which the ones with Italy and Finland are applied until today. Between 1980 and 1990 have been closed 15 conventions, being applied until today the ones signed with Japan, France, Norway, Cyprus, Sweden, Switzerland, Belgium, Greece, Netherlands, Bosnia and Herzegovina. In the period $1990-2000$ have been signed other 30 agreements and after the year of 2000 other 23 new agreements have been closed, the most recent being with Georgia, Saudi Arabia and Luxemburg.

Regarding avoidance of international double taxation of incomes, Hungary has a number of 12 conventions signed, the first treaty was with South Korea in 1989, followed by Denmark, treaty which was modified in 2011. After the year of 2000 have been closed conventions with India, Island, San Marino, Hong Kong, Taipei, Mexico, United Arab Emirates, Kosovo, Bahrain and the last, in 2015 with Liechtenstein.

Besides these, have been closed agreements to avoid double taxation of inheritances with Austria, Romania and Sweden, and for a better cooperation all these were completed by protocols, signed with Canada, Kuwait, Poland and Uzbekistan. 
Regarding Romania, there have been closed three types of treaties to avoid international double taxation, mostly about avoiding double taxation of incomes and capital. First convention was signed in the year of 1973 with Germany, these being modified in 2002. By 1980 have been closed conventions with France, USA, Great Britain, Italy, Denmark, Sweden and Spain, and between 1980 and 1990 have continued with Netherlands, Norway, Cyprus, Zambia, Jordan, Sri Lanka, Turkey, Bosnia and Herzegovina, Tunisia and Syria, subsequent being brought chances and additions in accords with Morocco, Netherlands, Syria and Norway. In period 1990 - 2000 have been signed 18 treaties, and after the year of 2000 other 23 new conventions, the most recent being sign with Uruguay in 2013.

To avoid double taxation of incomes have been closed agreements, first in 1976 with Japan, following the ones closed with Egypt, Bangladesh, Malaysia, China, Nigeria, Philippines, Malta, Thailand, Indonesia and Israel. After the year of 2000 have been signed agreements with Australia, Qatar, Island, Saudi Arabia and India. In this year, Romania has modified and updated agreements with Bulgaria and Norway.

Romania also has closed four protocols with Switzerland and San Marino since 2011, with Luxemburg since 2012 and with Austria since 2013.

\section{Conclusions}

A convention to avoid double taxation is, in stricto sensu, a mutual agreement which is closed by two states with the purpose of preventing the taxpayer of one country or in some cases of both countries to be taxed for the same income or capital in both states.

Double taxation can have both juridical and economic connotations. From a juridical point of view, double taxation occurs in the situation in which two or even more states tax simultaneously the same income or capital, while the economic double taxation occurs when two different persons are taxed based on same income and/or capital.

The reforms imposed to countries by the globalization process, through stimulation of fiscal competition between countries, were materialized in the desire of some countries to export a part from fiscal pressure. Also, globalization potentiated elasticity and movement of tax rates, but also raised a serial new problems regarding tax administration in the new conditions.

Problems which economic and juridical double taxation rise, mutadis mutandis, also refer to registration of different abuses that are manifested by applying the convention to avoid double taxation as a result of notification for some legislative gaps remarked on both sides of the barricades. Moreover, the treaty shopping practices which "circulate" in parallel with conventions to avoid double taxation 


\section{JOURNAL OF LEGAL STUDIES}

"Vasile Goldiş" Western University of Arad

Dumiter F., Jimon S. (2016)

Double Taxation Conventions in Central and Eastern European Countries

will be, in our opinion, in the future ,the Trojan horse" of convention to avoid double taxation.

Regarding exsocialist countries from Central and Eastern Europe we can notice that numerous economic and legal reforms made in the transition process were felt fully present. However the catching up process which these countries have to go through rises several problems and barriers that these have to overcome, especially in the economic and juridical field.

Analyzing the conventions to avoid double taxation from Central and Eastern Europe we could notice the use with predilection of the model published by the Organisation for Economic Co-operation and Development in the existing treaties. The oldest treaty is dated in 1937 and its interest is avoiding double taxation of inheritances, but most of agreements have been closed between 1990 and 2010, and the most recent one was signed in 2015.

Most of these treaties are concerned with avoiding double taxation of incomes and capital, but there are also agreements focused only on incomes, contributions for social security, inheritances, sea and air transport. In the Poland case there is a difference of only 11 conventions between the ones regarding incomes and capital and the ones regarding only incomes.

The main method to avoid double taxation is giving a fiscal credit for paid tax in a partner state, although there are also cases in which an exemption from taxation is given, in Slovakia and Hungary cases or a deduction, in the Czech Republic case.

In the case in which there is not an international treaty closed to avoid international double taxation, the Czech Republic and Hungary established in domestic legislation stipulations for avoiding this situation, giving it an exemption and respectively, a fiscal credit for foreign paid taxes.

In conclusion, we consider to be beneficial the accomplishment of some bilateral treaties, as well as taking some unilateral measures to avoid international double taxation and strengthening the international trade relationships.

\section{References}

[1] Reimer, E., Rust, A., Klaus Vogel on Double Taxation Conventions - Fourth Edition, Vol. II, Wolters Kluwer Law \& Business, 2015.

[2] Éva Erdős, Conflicts in the international tax law and answers of the european tax law, Curentul Juridic, Târgu Mureș, Vol.47, 2011, pp. 159-174.

[3] Ioan Rus, Eleonora-Laura Avram, Paula Monica Bocicor, Mirela Ruxandra Republic of Moldovan, Evitarea dublei impuneri între România și statele: Ungaria și Bulgaria, Academica Science Journal Studia Series, Tîrgu Mureș, Nr.(3)-2, 2013, pp. 50-57.

[4] Brian Caster, After NatWest: how courts should handle OECD commentary in double taxation treaty interpretations, Northwestern University Law Review Vol. 105, No. 3, 2011, pp. 1317-1346. 
[5] Michael S. Kirsch, The Limits of Administrative Guidance in the Interpretation of Tax Treaties, Texas Law Review Volume 87, Number 6, 2009, pp. 1063-1135.

[6] C John Taylor, Twilight of the neanderthals, or are bilateral double taxation treaty networks sustainable?, Melbourne University Law Review, Vol. 34, 2010, pp. 268-311.

[7] Bert J Zarh, Double Tax Treaties-The Basics and Benefits, THE CPA JOURNAL, 2011, pp. 50-53.

[8] Fabian Barthel, Matthias Busse, Eric Neumayer, The impact of double taxation treaties on foreign direct investment: evidence from large dyadic panel data, Contemporary Economic Policy, Vol. 28, nr. 3, 2010, pp. 366-377.

[9] *** - Manualul afacerilor europene, Institutul European din Romania (IER) University of Leuven - Belgia.

[10] Dănuț Chilarez, George Sebastian Ene, Harmonisation and fiscal competition in the European Union, Management Strategies Journal, Vol. 23, Nr. 1, 2014, pp. 83-93.

[11] Ioan Condor, Evitarea dublei impuneri internaţionale, Editura Regia Autonomă „Monitorul Oficial”, Bucureşti, 1999.

[12] Cosmin Şerbănescu, Lucian Ţaţu, Dan Ştefan, Delia Cataramă, Adrian Nica, Emilian Miricescu, Fiscalitate: de la lege la practica, Editura C.H. Beck, Bucuresti, 2013

[13] Limor Riza, Taxpayers' Lack of Standing in International Tax Dispute Resolutions: An Analysis Based on the Hybrid Norms of International Taxation, Pace law review, Vol.34:3, 2014, pp. 1064-1092.

[14] Genta Tafa (Bungo), Analysing double taxation: the Albanian case, International Journal of Management Cases, Volume 15, Nr. 3, 2013, pp. 109-121.

[15] Cornelia Lefter, Simona Chirică, Evitarea dublei impuneri internaţionale (Reglementări legale interne şi convenţii fiscale încheiate de România), Economie teoretică şi aplicată, Volumul XVII, Nr. 9(550), 2010, pp. 38-51.

[16] *** - Tax guides and highlights, Deloitte International Tax Source - disponibil on-line la adresa: https://dits.deloitte.com/\#TaxGuides, consultat în data de 08.09.2016 
Dumiter F., Jimon S. (2016)

Double Taxation Conventions in Central and Eastern European Countries

Appendix 1: Conventions to avoid international double taxation closed by Central and Eastern European countries

\begin{tabular}{|c|c|c|c|c|}
\hline Country & $\begin{array}{c}\text { Agreement } \\
\text { type }\end{array}$ & $\begin{array}{l}\text { Number } \\
\text { of partner } \\
\text { countries }\end{array}$ & Partner countries & $\begin{array}{c}\text { Date of } \\
\text { first/last } \\
\text { closed } \\
\text { agreement }\end{array}$ \\
\hline \multirow[t]{4}{*}{$\begin{array}{c}\text { Czech } \\
\text { Republic }\end{array}$} & $\begin{array}{c}\text { Income and } \\
\text { capital }\end{array}$ & 69 & $\begin{array}{l}\text { Albania, Armenia, Australia, Belgium, } \\
\text { Belarus, Bosnia - Herzegovina, Brazil, } \\
\text { Bulgaria, Canada, Croatia, Cyprus, } \\
\text { Denmark, Egypt, Estonia, Finland, } \\
\text { France, Georgia, Germany, Greece, } \\
\text { Hungary, Island, India, Indonesia, Ireland, } \\
\text { Israel, Italy, Japan, Kazakhstan, Kuwait, } \\
\text { South Korea, Latvia, Lebanon, Lithuania, } \\
\text { Luxemburg, Malaysia, Malta, Macedonia, } \\
\text { Mexico, Republic of Republic of } \\
\text { Moldova, Mongolia, Netherlands, } \\
\text { Nigeria, Norway, Philippines, Poland, } \\
\text { Portugal, Romania, Russia, Serbia, } \\
\text { Singapore, Slovakia, Slovenia, South } \\
\text { Africa, Spain, Sri Lanka, Sweden, } \\
\text { Switzerland, Thailand, Tunisia, Turkey, } \\
\text { Tajikistan, Ukraine, UAE, Great Britain, } \\
\text { USA, Uzbekistan, Venezuela, Vietnam }\end{array}$ & $\begin{array}{l}01.06 .1973 / \\
21.12 .2012\end{array}$ \\
\hline & Income & 11 & $\begin{array}{l}\text { Azerbaijan, Bahrain, Barbados, China, } \\
\text { Ethiopia, Jordan Hong Kong, Morocco, } \\
\text { Saudi Arabia, New Zeeland, Syria }\end{array}$ & $\begin{array}{l}15.04 .1980 / \\
01.05 .2013\end{array}$ \\
\hline & $\begin{array}{c}\text { Air } \\
\text { transport }\end{array}$ & 1 & Switzerland & 26.04 .1960 \\
\hline & $\begin{array}{c}\text { Social } \\
\text { security }\end{array}$ & 1 & USA & 07.09 .2007 \\
\hline TOTAL & $\mathbf{4}$ & 82 & - & - \\
\hline \multirow[t]{2}{*}{ Poland } & $\begin{array}{c}\text { Income and } \\
\text { capital }\end{array}$ & 50 & $\begin{array}{l}\text { Albania, Algeria, Armenia, Austria, } \\
\text { Azerbaijan, Belgium, Bosnia - } \\
\text { Herzegovina, Bulgaria, Chile, Canada, } \\
\text { Croatia, Cyprus, Czech Republic, } \\
\text { Denmark, Egypt, Estonia, Finland, } \\
\text { France, Georgia, Germany, Greece, } \\
\text { Hungary, Island, Kuwait, Latvia, } \\
\text { Lebanon, Lithuania, Luxemburg, Macao- } \\
\text { China, Macedonia, Republic of Republic } \\
\text { of Moldova, Mongolia, Morocco, } \\
\text { Norway, Romania, Russian Federation, } \\
\text { Serbia, Slovakia, Slovenia, Spain, Sri } \\
\text { Lanka, Switzerland, Tajikistan, Turkey, } \\
\text { UAE, Great Britain, USA, Uruguay, } \\
\text { Zambia, Zimbabwe }\end{array}$ & $\begin{array}{c}18.12 .1972 / \\
09.09 .2009\end{array}$ \\
\hline & Income & 39 & Saudi Arabia, Australia, Belarus, & $25.10 .1974 /$ \\
\hline
\end{tabular}




\begin{tabular}{|c|c|c|c|c|}
\hline & & & $\begin{array}{l}\text { Bangladesh, China, Ethiopia, Philippines, } \\
\text { Guernsey, Man Island, Jordan, India, } \\
\text { Indonesia, Iran, Ireland, Israel, Italy, } \\
\text { Japan, Jersey, Kazakhstan, South Korea, } \\
\text { Kyrgyzstan, Malaysia, Malta, Mexico, } \\
\text { New Zeeland, Nigeria, Pakistan, Portugal, } \\
\text { Qatar, Netherlands, South Africa, } \\
\text { Sweden, Singapore, Syria, Thailand, } \\
\text { Tunisia, Ukraine, Uzbekistan, Vietnam }\end{array}$ & 13.07.2015 \\
\hline & $\begin{array}{l}\text { Sea and air } \\
\text { transport }\end{array}$ & 5 & $\begin{array}{l}\text { Argentina, Switzerland, Guernsey, Jersey, } \\
\text { Man Island }\end{array}$ & $\begin{array}{c}28.12 .1950 / \\
10.08 .2013\end{array}$ \\
\hline & $\begin{array}{c}\text { Social } \\
\text { security }\end{array}$ & 1 & Macedonia & 06.04 .2006 \\
\hline & Protocol & 15 & $\begin{array}{l}\text { Austria, Belgium, Cyprus, Denmark, } \\
\text { India, Iran, Island, South Korea, } \\
\text { Luxemburg, Malta, Norway, Slovakia, } \\
\text { Switzerland, Hungary, UAE }\end{array}$ & $\begin{array}{l}27.06 .2000 / \\
14.04 .2014\end{array}$ \\
\hline TOTAL & 5 & 110 & - & - \\
\hline \multirow[t]{4}{*}{ Slovakia } & $\begin{array}{l}\text { Income and } \\
\text { capital }\end{array}$ & 55 & $\begin{array}{l}\text { Australia, Austria, Belarus, Belgium, } \\
\text { Bosnia - Herzegovina, Brazil, Bulgaria, } \\
\text { Canada, China, Croatia, Cyprus, Czech } \\
\text { Republic, Denmark, Estonia, Finland, } \\
\text { France, Germany, Greece, Georgia, } \\
\text { Hungary, Island, India, Ireland, Israel, } \\
\text { Italy, Japan, Kazakhstan, Kuwait, Latvia, } \\
\text { Lithuania, Luxemburg, Macedonia, } \\
\text { Republic of Republic of Moldova, } \\
\text { Mongolia, Netherlands, Nigeria, Norway, } \\
\text { Poland, Portugal, Romania, Russian } \\
\text { Federation, Serbia, Slovenia, South } \\
\text { Africa, Spain, Sri Lanka, Sweden, } \\
\text { Switzerland, Taiwan, Tunisia, } \\
\text { Turkmenistan, Ukraine, Great Britain, } \\
\text { USA, Uzbekistan }\end{array}$ & $\begin{array}{l}01.06 .1973 / \\
13.11 .2012\end{array}$ \\
\hline & Income & 10 & $\begin{array}{l}\text { Egypt, Indonesia, Korea, Libya, Mexico, } \\
\text { Portugal, Singapore, Syria, Turkey, } \\
\text { Vietnam }\end{array}$ & $\begin{array}{l}02.04 .1997 / \\
20.02 .2009\end{array}$ \\
\hline & $\begin{array}{c}\text { Air } \\
\text { transport }\end{array}$ & 1 & Switzerland & 26.04 .1960 \\
\hline & Protocol & 3 & Poland, Switzerland, Netherlands & $\begin{array}{l}16.02 .1996 / \\
01.08 .2013 \\
\end{array}$ \\
\hline TOTAL & 3 & 69 & - & - \\
\hline Hungary & $\begin{array}{l}\text { Income and } \\
\text { capital }\end{array}$ & 64 & $\begin{array}{l}\text { Albania, Armenia, Australia, Austria, } \\
\text { Azerbaijan, Belarus, Belgium, Bosnia - } \\
\text { Herzegovina, Brazil, Bulgaria, Canada, } \\
\text { China, Croatia, Cyprus, Czech Republic, } \\
\text { Egypt, Estonia, Finland, France, Georgia, } \\
\text { Germany, Greece, Indonesia, Ireland, } \\
\text { Israel, Italy, Japan, Kazakhstan, Kuwait, }\end{array}$ & $\begin{array}{l}25.02 .1975 / \\
2014\end{array}$ \\
\hline
\end{tabular}


Dumiter F., Jimon S. (2016)

Double Taxation Conventions in Central and Eastern European Countries

\begin{tabular}{|c|c|c|c|c|}
\hline & & & $\begin{array}{l}\text { Lebanon, Lithuania, Luxemburg, } \\
\text { Macedonia, Malaysia, Malta, Republic of } \\
\text { Republic of Moldova, Mongolia, } \\
\text { Morocco, Netherlands, Norway, Pakistan, } \\
\text { Philippines, Poland, Portugal, Romania, } \\
\text { Russian Federation, Serbia, Singapore, } \\
\text { Slovakia, Slovenia, Saudi Arabia, South } \\
\text { Africa, Spain, Sweden, Switzerland, } \\
\text { Thailand, Tunisia, Turkey, Ukraine, Great } \\
\text { Britain, USA, Uruguay, Uzbekistan, } \\
\text { Vietnam }\end{array}$ & \\
\hline & Income & 13 & $\begin{array}{l}\text { Bahrain, Denmark, Hong Kong, Island, } \\
\text { India, Kosovo, Korea, Liechtenstein, } \\
\text { Mexico, Qatar, San Marino, Taipei, UAE }\end{array}$ & $\begin{array}{l}23.03 .1989 / \\
2015\end{array}$ \\
\hline & Inheritances & 3 & Austria, Romania, Sweden & $1937 / 1976$ \\
\hline & Protocol & 4 & Canada, Kuwait, Poland, Uzbekistan & $1999 / 2015$ \\
\hline TOTAL & 4 & 84 & - & - \\
\hline Romania & $\begin{array}{l}\text { Income and } \\
\text { capital }\end{array}$ & 70 & 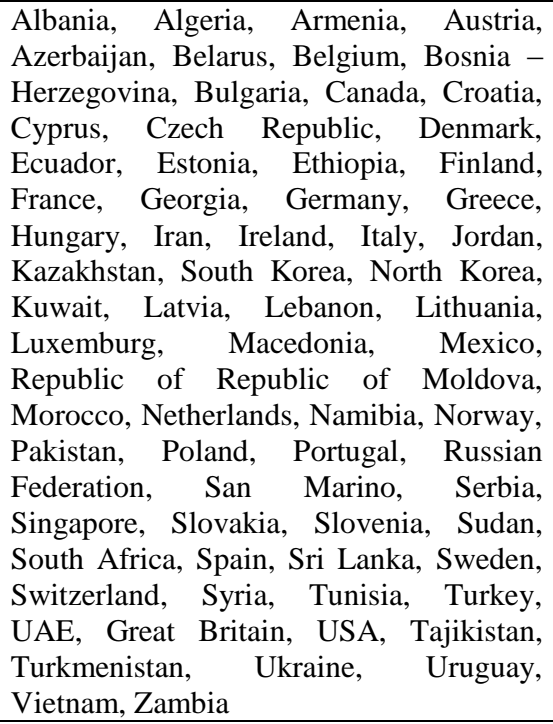 & $\begin{array}{l}04.12 .1973 / \\
24.10 .2013\end{array}$ \\
\hline & Income & 16 & $\begin{array}{l}\text { Saudi Arabia, Australia, Bangladesh, } \\
\text { China, Egypt, Philippines, India, } \\
\text { Indonesia, Island, Israel, Japan, Malaysia, } \\
\text { Malta, Nigeria, Qatar, Thailand }\end{array}$ & $\begin{array}{l}05.07 .1976 / \\
05.12 .2013\end{array}$ \\
\hline & Protocol & 4 & $\begin{array}{l}\text { Australia, Switzerland, Luxemburg, San } \\
\text { Marino }\end{array}$ & $\begin{array}{l}06.06 .2011 / \\
17.07 .2013 \\
\end{array}$ \\
\hline TOTAL & 3 & 90 & - & - \\
\hline
\end{tabular}

Source: Authors construction based on the information available on the UNCTAD, European Commission and Ministries of Finance databases. 